\title{
Cytogenetic damage related to low levels of methyl mercury contamination in the Brazilian Amazon
}

\author{
MARÚCIA I. M. AMORIM ${ }^{1}$, DONNA MERGLER ${ }^{2}$, MARCELO O. BAHIA $^{3}$ \\ HÉLÈNE DUBEAU ${ }^{4}$, DANIELA MIRANDA ${ }^{1}$, JEAN LEBEL ${ }^{2}$ \\ ROMMEL R. BURBANO ${ }^{1}$ and MARC LUCOTTE ${ }^{5}$ \\ ${ }^{1}$ Depto. de Biologia do CCB, Universidade Federal do Pará (UFPA) \\ ${ }^{2}$ Centre pour l'Étude des Interactions Biologiques entre la Santé et l'Environnement (CINBIOSE) \\ Université du Québec à Montréal (UQAM) \\ ${ }^{3}$ Depto. de Patologia do CCB, Universidade Federal do Pará (UFPA) \\ ${ }^{4}$ Depto. de Ciências Biológicas, Université du Québec à Montréal (UQAM) \\ ${ }^{5}$ Chaire de Recherche en Environnement H-Q / CRSNG / Université du Québec à Montréal (UQAM)
}

Manuscript received on May 2, 2000; accepted for publication on July 24, 2000;

presented by LEWIS J. GREENE

\begin{abstract}
The mercury rejected in the water system, from mining operations and lixiviation of soils after deforestation, is considered to be the main contributors to the contamination of the ecosystem in the Amazon Basin. The objectives of the present study were to examine cytogenetic functions in peripheral lymphocytes within a population living on the banks of the Tapajós River with respect to methylmercury ( $\mathrm{MeHg}$ ) contamination, using hair mercury as a biological indicator of exposure. Our investigation shows a clear relation between methylmercury contamination and cytogenetic damage in lymphocytes at levels well below $50 \mathrm{mi}-$ crograms/gram, the level at which initial clinical signs and symptoms of mercury poisoning occur. The first apparent biological effect with increasing $\mathrm{MeHg}$ hair level was the impairment of lymphocyte proliferation measured as mitotic index (MI). The relation between mercury concentration in hair and MI suggests that this parameter, an indicator of changes in lymphocytes and their ability to respond to culture conditions, may be an early marker of cytotoxicity and genotoxicity in humans and should be taken into account in the preliminary evaluation of the risks to populations exposed in vivo. This is the first report showing clear cytotoxic effects of long-term exposure to $\mathrm{MeHg}$. Although the results strongly suggest that, under the conditions examined here, $\mathrm{MeHg}$ is both a spindle poison and a clastogen, the biological significance of these observations are as yet unknown. A long-term follow-up of these subjects should be undertaken.
\end{abstract}

Key words: Brazilian Amazon, Mercury, Mitotic Index, Cytogenetics.

\section{INTRODUCTION}

Since the late seventies extensive gold mining operations using techniques based on amalgation with mercury have developed in the Amazon Basin. In close association with these mining activities, there

Correspondence to: Marcelo de Oliveira Bahia

E-mail: mbahia@ufpa.br has been important deforestation for population settlements and development of agriculture. The mercury rejected in the water system from mining operations and lixiviation of soils after deforestation is considered to be the main contributor to the contamination of the ecosystem (Roulet et al. 1998a).

Studies conducted in the region of the 
Tapajós River, a major affluent of the Amazon River, have shown that mercury is present in all environmental compartments (water, soil, plant) (Roulet et al. 1988b, c; Castilhos et al. 1998, Malm 1998). The biotransformation of inorganic mercury into methylmercury in aquatic environments is a well known process that makes human exposure possible through consumption of contaminated fish (WHO 1990, 1991). In the region of the Tapajós River, where fish is the dietary mainstay, methylmercury exposure levels in humans, measured in hair ranges from a few $\mu \mathrm{g} / \mathrm{g}$ up to $150 \mu \mathrm{g} / \mathrm{g}$; the median values reported are in the order of 10 to $20 \mu \mathrm{g} / \mathrm{g}$ (Nakanishi 1992, Pfeiffer et al. 1993, Grandjean et al. 1993, Lebel et al. 1998).

In vitro studies have shown that methylmercury is a cytotoxic agent; reduced mitotic index and chromosomal aberrations are induced in human lymphocytes treated in vitro with methylmercury (Bahia et al. 1999, Nakatsuru et al. 1985, Verschaeve et al. 1985, Betti et al. 1992, 1993a, b). Few studies have been performed on possible cytotoxic effects in human populations with methylmercury contamination and authors, reviewing these studies, have pointed out that the findings are borderline or inconclusive (Nickle 1999, De Flora et al. 1994). Although there are methodological problems with each of the studies (small sample size, no control group, confounding factors not taken into account), the overall picture suggests that there may be an association between methylmercury exposure and cytogenetic deficiencies.

In the early seventies, two studies from Sweden, which included 9 and 23 exposed persons respectively, suggested correlations between blood mercury levels and lymphocyte structural chromosomal aberrations (Skerving et al. 1970, 1974). In 17 patients with Minamata Disease, Kato and Nakamura (1976) reported a $18.7 \%$ frequency of chromosome breakage and a $2.6 \%$ frequency of chromosome reunions and rearrangements, however, there was no control group. A study of 16 fish-eating subjects from a polluted area in Colombia found no differences in the frequency of sister-chromatid exchanges compared to controls; the frequency of chromosomal aberrations was higher in the exposed group only when achromatic lesions were included (Monsalve \& Chiape 1987). In a larger scale study, Wulf et al. (1986) analyzed sister-chromatid exchanges in lymphocytes taken from 147 persons whose diet included seal meat; they showed mean frequencies 1.7 times higher in the heavy seal-meat eaters as compared to those who ate less; moreover, the frequency of sister-chromatid exchanges increased with increasing blood mercury levels. They did not report hair mercury levels, which may be a better indicator of longterm exposure.

The objectives of the present study were to examine cytogenetic functions in peripheral lymphocytes (mitotic index, polyploidal aberrations and chromatid breaks) among a population living on the banks of the Tapajós River with respect to methylmercury contamination, using hair mercury as a biological indicator of exposure.

\section{MATERIAL AND METHODS}

\section{Population}

Cytogenetic study of the analysed population was aproved by the Ethics Committees from the Conselho Nacional de Desenvolvimento Científico e Tecnológico $(\mathrm{CNPq})$ and the Universidade Federal do Pará, Belém - Pará, Brasil. The persons who participated in this study live in a small village, Brasília Legal, situated on the bank of the Tapajos River, an effluent of the Amazon ( $\left.3^{\circ} 59^{\prime} 00^{\prime \prime} \mathrm{S}, 55^{\circ} 30^{\prime} 00^{\prime \prime} \mathrm{W}\right)$. The village is approximately $250 \mathrm{~km}$ downstream from gold-mining operations and the villagers are not exposed to mercury vapours. Brasília Legal is accessible only by water, a 12 hour boat trip from Santarém, a city of several hundred thousand. There are minimal health facilities in Brasília Legal and electricity for only 3 hours every evening. The adult population ( $\geq 15$ years) is made up of approximately 250 persons.

Recruitment of study participants was carried out from house to house with the help of the local community health nursing aides. The study objec- 
tives were explained and villagers were invited to come to the Health Center where blood and hair samples were taken, and a questionnaire including socio-demographic information, smoking and drinking habits, medical and work history was administered by interview.

A total of 98 adults, ranging in age from 15-81 years, participated in the study. Their age distribution, which is similar to the overall population, is presented in Table I with other relevant characteristics: sex, smoking and drinking habits, a history of malaria and previous work in the gold mining region. For the current smokers, the number of cigarettes per day ranged from 1 to $4 ; 4 \%$ (3 persons) of the current drinkers reported drinking more than once or twice a week and only 2 persons reported previously using marijuana. One third $(33.3 \%)$ of the men and two of the women had worked in the gold mining region, where they would have been exposed to mercury vapours. It is in this area that most of the cases of malaria were contracted; of the 24 persons with a history of malaria, 15 (79\%) had worked in the gold mining region.

\section{Cytogenetic Techniques}

Blood was obtained in heparinized vacutainers by venupuncture. In order to avoid potential loss of viability associated with transport and delay, cultures were prepared on the boat, using electricity provided by a generator. The blood was stored immediately in a refrigerator and within a maximum of 4 hours, two independent cultures were set up by adding 12 drops of whole blood in 5ml of RPMI 1640 (GIBCO), containing $20 \%$ fetal calf serun (Cultilab) with antibiotics (100 IU penicilin/ml and $100 \mu \mathrm{g}$ streptomycin/ml, GIBCO) and 4\% phytohemoagglutinin (Cultilab). Cultures were incubated in a controlled water-bath at $37^{\circ} \mathrm{C}$ for $48 \mathrm{~h}$. Colchicine $(0.8 \mathrm{mM}$, Sigma) was added to the cultures $2 \mathrm{~h}$ before harvest to obtain a maximum of cells at metaphase.

Cells were harvested by centrifugation (1000 $\mathrm{rpm} / \mathrm{min}$ ) and treated during 10 minutes with $\mathrm{KCl}$ (0,075 M, MERCK). They were fixed with Carnoy fixative 1:3 (glacial acetic acid:absolute methanol).
TABLE I

Characteristics of the study participants.

\begin{tabular}{|c|c|c|}
\hline & $\mathrm{n}$ & $\%$ \\
\hline \multicolumn{3}{|l|}{ age category } \\
\hline$\geq 15<25$ & 35 & 35.7 \\
\hline$\geq 25<35$ & 24 & 24.5 \\
\hline$\geq 35<45$ & 17 & 17.3 \\
\hline$\geq 45<55$ & 12 & 12.3 \\
\hline$\geq 55$ & 10 & 10.2 \\
\hline \multicolumn{3}{|l|}{$\operatorname{sex}$} \\
\hline women & 46 & 46.9 \\
\hline men & 52 & 53.1 \\
\hline \multicolumn{3}{|l|}{ smoking habits } \\
\hline non-smoker & 51 & 52.0 \\
\hline ex-smoker & 29 & 20.4 \\
\hline smoker & 27 & 27.6 \\
\hline \multicolumn{3}{|c|}{ alcoholic beverages } \\
\hline non-drinker & 37 & 37.8 \\
\hline drinker & 61 & 62.2 \\
\hline \multicolumn{3}{|l|}{ malaria } \\
\hline no & 72 & 74.2 \\
\hline yes & 25 & 25.8 \\
\hline \multicolumn{3}{|l|}{ gold mining region } \\
\hline never & 78 & 80.4 \\
\hline yes & 19 & 19.6 \\
\hline
\end{tabular}

Slides were prepared, air-dried and stained for 10 minutes with 3\% Giemsa stain (MERCK) diluted in buffer solution ( $\mathrm{pH}=6.8$ ).

The slides were analyzed, using light microscopy, in the Cytogenetic Laboratory at the Federal University of Pará in Belém, Brazil. For lymphocyte analyses, one of the two cultures that were collected for each individual, was selected randomly. If the selected culture showed poor proliferative potential, the other one was used. At least one culture was adequate for every person. The mitotic index (MI) (frequency of metaphase nuclei in 1000 nuclei) and the number of polyploidal aberrations (PA) in 1000 cell was determined for each individual. For chromatid breaks, 100 clear metaphases were analyzed for each culture. The observers were unaware of subjects' exposure levels. 


\section{Hair SAMPling AND ANALYSES}

Hair strands from the root were taken from the occipital region and then placed in plastic bags, with the root end stapled. Analyses for mercury determination were conducted in the laboratories of the Environmental Research Chair of the University of Québec in Montréal, using Cold Vapor Atomic Fluorescence spectrophotometry (CVAF).

Hair strands were cut in one $\mathrm{cm}$ segments and each segment was analyzed for total mercury, according to the procedure described by Bloom and Fitzgerald (1988) and adapted for hair. Inorganic mercury determination was done on the first segment using the methods described by Farant et al. (1981) and adapted for CVAF. Analytical quality was ensured by including a Health Canada sample of powdered hair in the series. In the present analysis, the mean value for total mercury of the 2 first centimeters was used.

\section{RESULTS}

\section{Hair Mercury Levels}

Total hair mercury levels for this population was $\log$ normally distributed and ranged from $0.57 \mu \mathrm{g} / \mathrm{g}$ to $153.8 \mu \mathrm{g} / \mathrm{g}$. The latter however was an outlier and is treated separately in the analyses, the next highest value was $71.85 \mu \mathrm{g} / \mathrm{g}$. The median level was $13.50 \mu \mathrm{g} / \mathrm{g}$, with $7.95 \mu \mathrm{g} / \mathrm{g}$ and $22.19 \mu \mathrm{g} / \mathrm{g}$, the 25 th and 75 th quartile values, respectively. Women have significantly lower levels (median: $10.8 \mu \mathrm{g} / \mathrm{g}$ ) as compared to men (median: $17.08 \mu \mathrm{g} / \mathrm{g}$; MannWhitney $U=823.5 ; p<0.05)$. There was no relation between hair mercury levels and smoking status, alcohol consumption, age, having worked in the garimpos or having suffered from malaria.

\section{Mitotic IndeX}

For the participants in this study, the mitotic index ranged from 8 to 36 per 1000 cells, with a mean of $25.20 \pm 7.8$. Table II presents the mean mitotic indices with respect to the relevant characteristics of the group. Women had a significantly higher index as compared to men. Although smokers pre-

\section{TABLE II}

Mean mitotic index per 1000 cells with respect to the characteristics of the study participants.

\begin{tabular}{lll}
\hline & \multicolumn{2}{c}{ Mitotic Index } \\
& mean & st. dev. \\
\hline age category & & \\
$\geq 15<25$ & 26.5 & 7.8 \\
$\geq 25<35$ & 24.2 & 7.4 \\
$\geq 35<45$ & 22.8 & 8.7 \\
$\geq 45<55$ & 23.7 & 8.3 \\
$\geq 55$ & 27.4 & 7.4 \\
sex & & \\
women & 27.1 & 6.8 \\
men & 23.2 & $8.4^{* *}$ \\
smoking habits & & \\
non-smoker & 26.0 & 7.7 \\
ex-smoker & 27.3 & 6.6 \\
smoker & $21.5^{*}$ & $8.2^{*}$ \\
alcoholic beverages & & \\
non-drinker & 27.4 & 6.9 \\
drinker & $23.7^{*}$ & 8.2 \\
malaria & & \\
no & 25.7 & 7.5 \\
yes & 22.8 & 8.5 \\
gold mining region & & \\
never & 26.0 & 7.5 \\
yes & 22.1 & 8.6 \\
\hline ANOVA. ${ }^{* *}$ p $<0.01{ }^{*} \mathrm{p}<0.05$. & \\
$\quad$ & &
\end{tabular}

sented a significantly lower mitotic index as compared to ex-smokers and non-smokers, when sex was entered into the model, this difference was no longer significant ( 2 factor ANOVA: sex: $\mathrm{F}=5.05$; $p=0.03$; smoking: $F=0.70$; ns). The same pattern was observed for alcohol consumption, with drinkers having a lower mitotic index as compared to non-drinkers, however, when sex was included in the model, neither variable was significant (2 factor ANOVA: sex: $\mathrm{F}=1.85$; ns; alcohol consumption: $\mathrm{F}=1.85$; ns). No significant differences were observed with age, malaria and having lived in the gold mining area.

The relation between mitotic index for women 
and men with respect to total hair mercury is presented in Figure 1. There appears to be an initial plateau where mitotic indices vary between 30 and 36; the relation is best described by a second degree polynomial $\left(\mathrm{r}^{2}=0.64 ; \mathrm{F}=84.5 ; \mathrm{p}<0.001\right)$ The outlier (not in the graph), whose HHg is $153.8 \mu \mathrm{g} / \mathrm{g}$ has a mitotic index of 12 .

\section{Polyploides}

The frequency of polyploides per 1000 lymphocyte cells ranged from 0 to 16 . The majority of participants $(63.9 \%)$ did not present this aberration. The distribution of persons with polyploidal aberrations (PA) with respect to the characteristics of the group are presented in Table III. Although proportionally more men than women presented PA, the difference did not attain statistical significance. Polyploidal aberrations were observed significantly more frequently among alcohol drinkers as compared to nondrinkers and among those who had lived in the gold mining region as compared to those who had not. When stratified according to sex, these differences are no longer present.

Figure 2 shows the relation for women and men for PA frequency and hair mercury level. The lowest level at which PAs are observed is $7.25 \mu \mathrm{g} / \mathrm{g}$ $\mathrm{HHg}$. Above this level there is an increase in both the number of aberrations observed as well as the relative frequency of persons presenting them. Using 7.25 as a cut-off point, the simple regression line between the frequency of polyploidal aberrations and total hair mercury level is highly significant $\left(r^{2}=0.41 ; F=51.7 ; p<0.001\right)$. At $\mathrm{HHg} \geq$ $20 \mu \mathrm{g} / \mathrm{g}$, the prevalence of persons with polyploidal aberrations is $86.7 \%$ as compared to $18.8 \%$ for those with $\mathrm{HHg} \geq 10 \mu \mathrm{g} / \mathrm{g}<20 \mu \mathrm{g} / \mathrm{g}$ and $8.8 \%$ for those with levels below 10 . The differences are highly significant (Chi square: 48.9, df=2; $p<0.001$ ). A total of 16 polyploides per 1000 cells were observed for the outlier.

\section{Chromatid Breaks}

Between 1-3 breaks were observed in lymphocytes for 14 persons (14.6\%); for 11 there was only one

\section{TABLE III}

\section{Distribution of persons with polypoidal aber- rations with respect to the characteristics of the study participants.}

\begin{tabular}{lcc}
\hline & \multicolumn{2}{c}{ Polyploidal aberrations } \\
& $\mathrm{n}$ & $\%$ \\
\hline age category & & \\
$\geq 15<25$ & 9 & 25.7 \\
$\geq 25<35$ & 13 & 54.2 \\
$\geq 35<45$ & 7 & 43.8 \\
$\geq 45<55$ & 4 & 33.3 \\
$\geq 55$ & 2 & 20.0 \\
sex $\quad$ & \\
$\quad$ women & 12 & 26.1 \\
men & 23 & 45.1 \\
smoking habits & & \\
non-smoker & 16 & 45.7 \\
ex-smoker & 6 & 17.1 \\
smoker & 13 & 37.1 \\
alcoholic beverages & & \\
non-drinker & 8 & 21.6 \\
drinker & 27 & $45.0^{*}$ \\
malaria & & \\
no & 22 & 31.0 \\
yes & 13 & 52.0 \\
gold mining region & & \\
never & 23 & 29.9 \\
yes & 11 & $57.9^{*}$ \\
\hline Chi square: & &
\end{tabular}

Chi square: ${ }^{*} \mathrm{p}<0.05$.

break, for 2 there were 2 breaks and 1 person presented 3 breaks. The only characteristic that distinguishes those with breaks from those without is the level of $\mathrm{HHg}$; those with chromatid breaks have significantly higher levels of $\mathrm{HHg}$ as compared to those without $(30.46 \mu \mathrm{g} / \mathrm{g} \pm 10.7$ vs $14.5 \mu \mathrm{g} / \mathrm{g} \pm$ 11.6; ANOVA $\mathrm{F}=23.3 ; \mathrm{p}<0.001)$. Among those with $\mathrm{HHg} \geq 20 \mu \mathrm{g} / \mathrm{g}$, the prevalence of persons with breaks is $37.9 \%$, as compared to $9.4 \%$ for those with $\mathrm{HHg} \geq 10 \mu \mathrm{g} / \mathrm{g}<20 \mu \mathrm{g} / \mathrm{g}$; none of the persons with $\mathrm{HHg}$ levels below 10 presented breaks. The differences are highly significant (Chi square: $19.4, \mathrm{df}=2$; $\mathrm{p}<0.001)$. 


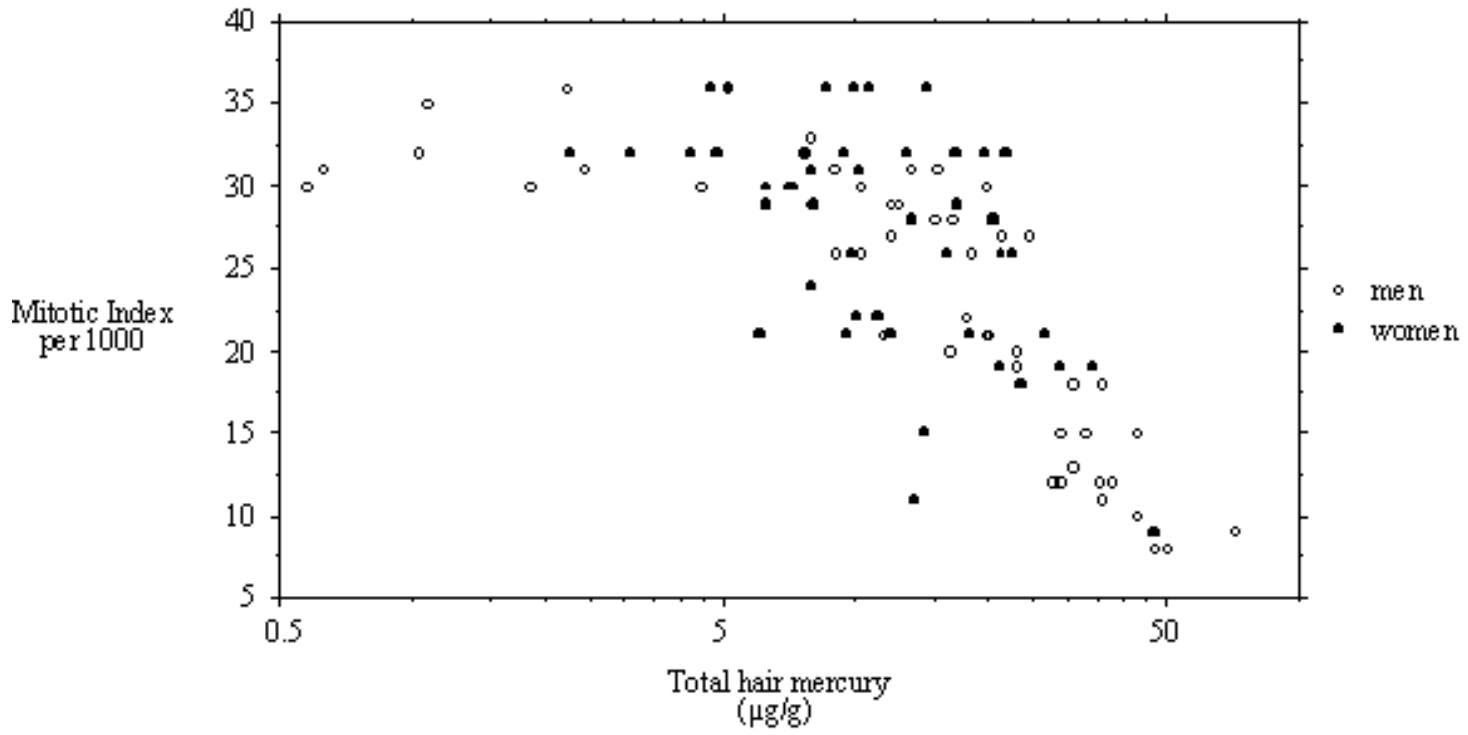

Fig. 1 - Relation between mitotic index for men and woman with respect to total hair mercury.

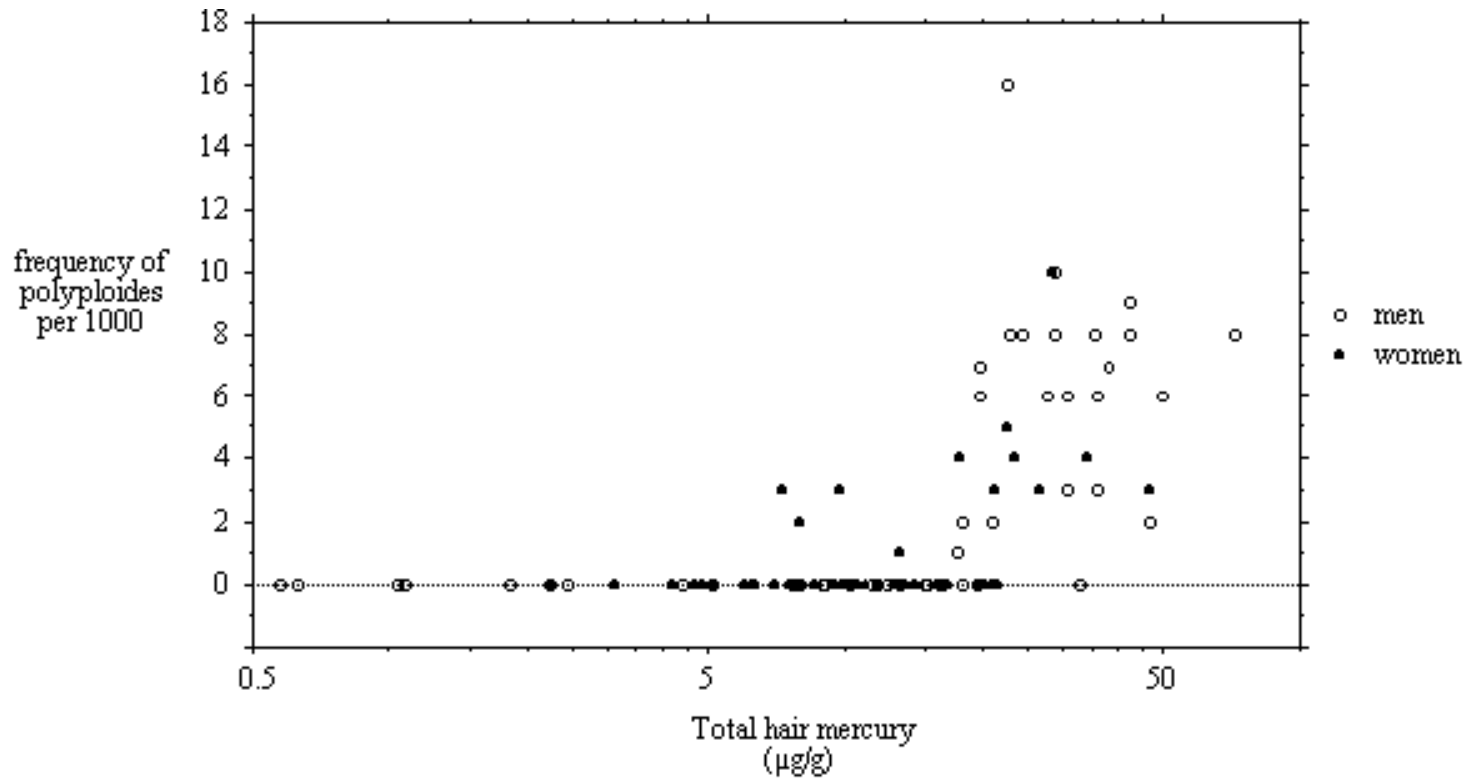

Fig. 2 - Relation for men and woman for polyploidal aberrations frequency and hair mercury level.

\section{DISCUSSION}

The findings of this study show a clear relation between methylmercury contamination and cytogenetic damage in lymphocytes at levels well below $50 \mu \mathrm{g} / \mathrm{g}$, the level at which initial clinical signs and symptoms of mercury poisoning occur (IPCS 1990). The first apparent biological effect with increasing $\mathrm{MeHg}$ hair level was the impairment of lymphocyte proliferation measured as mitotic index, the proportion of cells in M-phase of the cell cycle (Rojas et al. 1993). Decreased MI reflects inhibition 
of cell-cycle progression and/or loss of proliferative capacity. During in vitro experiments on chromosomal aberrations, variation in MI is used to monitor induced cellular toxicity. This information on the degree of cytotoxicity is essential to adequately select harvest time and test concentration, and is especially important when the results are used in risk assessment of compounds to which humans may be exposed. Mitotic index suppression has been suggested for use in dose selection for cytogenetic testing for regulatory purposes (UKEMS 1990). However, this parameter is rarely considered for in vivo studies.

The relation between mercury concentration in hair and MI suggest that this parameter, an indicator of changes in lymphocytes and their ability to respond to culture conditions, may be an early marker of cytotoxicity and genotoxicity in humans and should be taken into account in the preliminary evaluation of the risks to populations exposed in vivo. In a study of chronic exposure to another metal, arsenic (As), impairment of lymphocyte proliferation was observed in exposed individuals as compared to controls (Ostrosky-Wegman et al. 1991, Gonsebatt et al. 1994).

In this Amazonian population, no specific effect of age on proliferative ability of lymphocytes was observed. These results are similar to other human studies which reported no variation in lymphocyte proliferative rate with age in a control group from the United Kingdom (Anderson et al. 1988). Similarly, the sex-related differences in mitogeninduced lymphocyte proliferation observed here are in conformity with others. In non-exposed individuals, Anderson et al. (1991), observed higher blastogenic transformation in PHA stimulated lymphocytes from women as compared to men. Although Gonsebatt et al. 1994 report a greater impairment of lymphocytes in women exposed to arsenic in drinking water as compared to men, they have no measure of dose, which may prove to be higher in women. Sager et al. (1984) reported that the number of cells in the developing cerebellar external layer in 2-dayold mice was significantly reduced after methylmer- cury treatment in males but remained unaltered in females.

The fact that exposure was associated with changes in the proliferative potential of lymphocytes raises the question of possible immunological implications. There is a large experimental data base on the immunosuppressive properties of metals, their inorganic salts and organometallic components (Koller 1980). Methylmercury, together with calcium, lead and As, have shown to cause immunological changes in laboratory animals (NRC 1992). The observed reduced lymphocyte proliferation associated with low levels of mercury may translate into reduced resistance to disease in this Amazonian population.

The positive results found for polyploidy and chromatid breaks with mercury exposure and their appearance following MI perturbations are in agreement with the molecular mechanism of action inferred from in vitro observations. The genotoxicity of mercury is generally attributed to its binding with tubulin-SH, causing the impairment of spindle function and chromosome segregational error during cell division (Onfelt 1983, Sager et al. 1983). This has been regarded as the cause of the increased frequency of polyploidy and aneuploidy in Allium and Drosophila (Ramel \& Magnusson 1969, 1979, Ramel 1969, Fiskesjo 1988). Moreover, in vitro polymerization and depolymerization of microtubules is affected by $\mathrm{MeHg}$ (Vogel et al. 1985). This could explain some of the multiple effects of $\mathrm{MeHg}$ on the cell cycle, including a lengthened G1 and decreased transition probability after short term exposure of cycling cells, and a G2 accumulation after a longer term exposure (Vogel et al. 1986). Studies on the potentiating effects of organic and inorganic mercuries on clastogen-induced chromosome aberrations induced in $\mathrm{CHO}$ cells suggest that they inhibit some of the protein activities involved in the DNA repair process (Yamada et al. 1993).

The findings of the present study support the notion that methylmercury has a clastogenic effect, causing chromatid breaks. Mercury like other metals such as cadmium, chromium, zinc, magnesium 
and manganese may be genotoxic through generation of free oxygen radicals (Ochi et al. 1983, Cantoni et al. 1984a, b, Snyder 1988). Methylmercury is known to generate free radicals through induction of lipid peroxidation in animal tissue (Ganther 1978, Shinada et al. 1990). Therefore the observed breaks could result from free radical damage.

In contrast to inorganic mercury, methylmercury easily passes the placenta barrier at least in some species. The occurrence of prenatal intoxication in children shows that this is the case also in humans. It remains to be investigated whether tissues from exposed fetuses have an increased frequency of cells with polyploids or chromatid breaks. It is not yet known whether it is associated with an increased frequency of spontaneous abortions. Theoretically, methylmercury-induced chromosome damage in germline cells could give rise to abnormal offspring.

This is the first report showing clear cytotoxic effects of long-term exposure to methylmercury. The group was sufficiently large with a wide range of mercury exposure, based on a well-known biological marker, hair mercury. In the situation of this riverbank population on the Tapajós River, it is estimated that exposure to mercury has been present over the past twenty years. Although the results strongly suggest that, under the conditions examined here, $\mathrm{MeHg}$ is both a spindle poison and a clastogen, the biological significance of these observations is as yet unknown. A long-term follow-up of these subjects should be undertaken. It is noteworthy that lower MIs preceded appearance of chromosomal endpoints such as polyploidy and chromatid breaks suggesting that MI may prove to be a valuable early indicator for this health hazard.

\section{ACKNOWLEDGEMENTS}

This work was supported by the International Development and Research Center (IDRC) of Canada as part of the CARUSO project (grant \#96-105201/001300-01) and Universidade Federal do Pará. The authors are grateful to Ms. Glorita Santos,
"Seu" Humberto da Silva, Francisco Borges (in memoriam), and Ana Maria Rodrigues for technical help.

\section{REFERENCES}

Anderson D, Jenkinson PC, Dewdeney RS, Francis AJ, Godbert P \& Butterworth KR. 1988. Chromosome aberrations, mitogen-induced blastogenesis and proliferative rate index in peripheral lymphocytes from 106 control individuals of the U.K. population. Mutat Res 204: 407-420.

Anderson D, Francis AJ, Godbert P, Jenkinson PC \& Butterworth KR. 1991. Chromosome aberrations (CA), sister-chromatid exchanges (SCE) and mitogen-induced blastogenesis in cultured peripheral lymphocytes from 48 control individuals sample 8 times over 2 years. Mutat Res 250: 467-476.

Bahia MO, Amorim MiM, Burbano RR, Vincent S \& Dubeau H. 1999. Genotoxic effects of mercury on in vitro cultures of human cells. An Acad Bras Ci 71(3-I): 437-443.

Betti C, Davini T \& Barale R. 1992. Genotoxic activity of methylmercury chloride and dimethyl mercury in human lymphocytes. Mutat Res 281: 255260.

Betti C, Barale R \& Pool-Zobel BL. 1993a. Comparative studies on cytotoxic and genotoxic effects of two organic mercury compounds in lymphocytes and gastric mucosa cells of Sprague-Dawley rats. Env Mol Mutag 22: 172-180.

Betti C, Davini T, HE J \& Barale R. 1993b. Liquid holding effects on methylmercury genotoxicity in human lymphocytes. Mutat Res 301: 267-273.

Bloom N \& Fitzgerald WF. 1988. Determination of volatile mercury species at the picogram level by low temperature gas chromatography with cold vapor atomic fluorescence detection. Anal Chim Acta 208: $151-161$.

Cantoni O, Christie NT, Swann A, Drath DB \& Costa M. 1984a. Mechanism of $\mathrm{HgCl}_{2}$ citotoxicity in cultured mammalian cells. Mol Pharmacology 26: 360-368.

Cantoni O, Christie NT, Robinson SH \& Costa M. 
1984b. Characterization of DNA lesions produced by $\mathrm{HgCl}_{2}$ in cell culture systems. Chem Biol Interact 49: 209-224.

Castilhos ZC, Bidone ED \& Lacerda LD. 1998. Increase of the background human exposure to mercury through fish consumption due to gold mining at the Tapajós River region, Pará State, Amazon. Bull Environ Contam Toxicol 61(2): 202-9.

De Flora S, Benniceli C \& Bagnasco M. 1994. Genotoxicity of mercury compounds. A review. Mutat Res 317: $57-79$.

Farant JP, Brisset D, Moncion L, Brigasand L \& Chartrand A. 1981. Improved cold vapor atomic absorption technique for the microdetermination of total and inorganic mercury in biological samples. $J$ Anal Toxicol 5: 47-51.

FISKESJO G. 1988. The Allium test. An alternative in environmental studies: the relative toxicity of metal ions. Mutat Res 197(2): 243-60.

GANTHER HE. 1978. Modification of methylmercury toxicity and metabolism by selenium and vitamin E: possible mechanisms. Environ Health Perspect 25: 71-76.

Gonsebatt ME, Vega L, Montero R, Garcia-Vargas G, Del Razo LM, Albores A, Cebrian ME \& Ostrosky-Wegman P. 1994. Lymphocyte replicating ability in individuals exposed to arsenic via drinking water. Mutat Res 313(2-3): 293-9.

Grandjean P, Cardoso B \& Guimarães G. 1993. Mercury poisoning. Lancet 342: 991.

iPCS (International Programme on Chemical SAFETY). 1990. Methylmercury Environmental Health Criteria, 101. World Health Organization, Geneva, p. 144.

Kato R \& NaKamura A. 1976. Chromosome breakage associated with organic mercury in human leukocytes "in vitro" and "in vivo". Jpn J Human Genet 20: 256-257.

KoLLER LD. 1980. Immunotoxicology of heavy metals. Int J Immunopharmacol 2: 269-279.

Lebel J, Mergler D, Branches F, Lucotte M, Amorim M, Larribe F \& Dolbec J. 1998. Neu- rotoxic effects of low-level methylmercury contamination in the Amazonian Basin. Environ Res Section A. 79: $20-32$.

MaLm O. 1998. Gold mining as a source of mercury exposure in the Brazilian Amazon. Environ Res 77(2): 73-8.

Monsalve MV \& Chiappe C. 1987. Genetic effects of methylmercury in human chromosomes: I. A cytogenetic study of people exposed through eating contamined fish. Environ Mol Mutagen 10: 367-376.

NAKANishi J. 1992. Mercury pollution: Minamata, Canada and Amazon. Water Rep 2: 4-5.

Nakatsuru S, Oohashi J, Nozaki H, Nakada S \& IMURA N. 1985. Effect of mercurials on lymphocyte functions "in vitro". Toxicology 36(4): 297-05.

NRC (National Research Council). 1992. Commission on Life Sciences, Board on Environmental Studies and Toxicology, Subcommittee on Immunotoxicology Committee on Biological Markers. Biological Markers in Immunotoxicology, National Academic Press, Washington, D.C., pp. 68-71.

NickLE RA. 1999. Mercury. Top of the hit parade for eight years. Drug Chem Toxicol 22(1): 129-142.

Ochi T, Takahashi K \& Ohsawa M. 1983. A mechanism for the stimulation by inorganic mercury of [3H] thymidine incorporation into DNA in cultured Molt-4F cells. Jpn J Exp Med 53: 187-94.

ONFelt A. 1983. Spindle disturbances in mammalian cells. I. Changes in the quantity of free sulfhydryl groups in relation to survival and C-mitosis in V79 Chinese hamster cells after treatment with colcemid, diamide, carbaryl and ethyl mercury. Chem Biol Interact 46: 201-17.

Ostrosky-Wegman P, Gonsebatt Me, Montero R, Vega L, Barba H, Espinosa J, Palao A, Cortinas C, Garcia-Vargas G, Del Razo LM \& CeBRIAN M. 1991. Limphocyte proliferation kinetics and genotoxic findings in a pilot study on individual chronically exposed to arsenic in Mexico. Mutat Res 250: $477-482$.

Pfeiffer WC, Lacerda LD, Salomons W \& Malm O. 1993. Environmental fate of mercury from gold- 
mining in the Brazilian Amazon. Environ Rev 1: 26-37.

RAMEL C. 1969. Genetic effects of organic mercury compounds. I. Cytological investigations on Allium roots. Hereditas 61(1): 208-230.

Ramel C \& Magnusson J. 1969. Genetic effects of organic mercury compounds. II. Chromossome segregation in Drosophila melanogaster. Hereditas 61(1): 231-54.

Ramel C \& Magnusson J. 1979. Chemical induction of nondisjunction in Drosophila. Environ. Health Perspec 31: 59-66.

Rojas E, Herrera LA, Sordo M, Gonsebatt ME Montero R, Rodriguez R \& Ostrosky-Wegman P. 1993. Mitotic index and cell proliferation kinetics for the identification of antineoplastic activity. AntiCancer Drugs 4: 637-640.

Roulet M, Lucotte M, Farella N, Serique G, Coelho H, Sousa Passos CJ, de Jesus da Silva E, Scavone de Andrade P, Mergler D, Guimarães J-RD \& AMORIM M. 1998a. Effects of recent human colonization on the presence of mercury in Amazonian ecosystems. Water, Air and Soil Pollution 00: $1-17$.

Roulet M, Lucotte M, Saint-Aubin A, Tran S, Rheault I, Farella N, de Jesus da Silva E, Dezencourt J, Sousa Passos C-J, Santos Soares G， Guimarães J-RD， Mergler D \& Amorim M. 1998b. The geochemistry of mercury in central Amazonian soils developed on the Alter-do-Chão formation of the lower Tapajós River Valley, Pará state, Brazil. Sci T Env 223: 1-24.

Roulet M, Lucotte M, Canuel R, Rheault I, Tran S, de Freitas GOG YG, Farella N, Souza do Vale R, Sousa Passos C-J, de Jesus da Silva E, Guimarães J-RD, Mergler D \& AMORIM M. 1998c. Distribution and partition of total mercury in waters of the Tapajós River Basin, Brazilian Amazon. Sci T Env 213: 203-211.

SAGER PR \& Syversen TL. 1984. Differential responses to methylmercury exposure and recovery in neuroblastoma and glioma cells and fibroblasts. Exp Neurol 85: $371-82$.
SAger PR, Doherty RA \& Olmsted JB. 1983. Interaction of methylmercury with microtubules in cultured cells and "in vitro". Exp Cell Res 146: 127-37.

Shinada M, Takizawa Y \& Muto H. 1990. Effect of mercuric chloride on phospholipid peroxidation in rat. Nippon Koshu Eisei Zasshi 37: 1010-4.

Skerfying S, Hansson K \& Lindsten J. 1970. Chromossome breakage in human exposed to methylmercury through fish consumption. Arch Environ Health 21: 133-139.

Skerfing S, Hansson K, Mangs C, Lindston J \& RYMAN N. 1974. Methylmercury-induced chromossome damage in man. Environ Res 7: 83-98.

SNYDER RD. 1988. Role of active oxygen species in metal induced DNA strand breakage in human diploid fibroblasts. Mutat Res 193: 237-246.

UKEMS. 1990. The third United Kingdom Environmental Mutagen Society collaborative trial. Mutagenesis (Sup. 5): 1-88.

Verschaeve L, Kirsch-Volders M, Hens L \& Susanne C. 1985. Comparative "in vitro" cytogenetic studies in mercury-exposed human lymphocytes. Mutat Res 157: $221-226$.

Vogel DG, Margolis RL \& Mottet NK. 1985. The effects of methylmercury binding to microtubules. Toxicol Appl Pharmacol 80: 473-86.

Vogel DG, Rabinovitch PS \& Mottet NK. 1986. Methylmercury effects on cell cycle kinetics. Cell Tissue Kinet 19(2): 227-42.

WHO, International Program on Chemical Safety. 1990. Environmental Health Criteria 101: Methylmercury. Geneva: World Health Organization, 144p.

WHO, International Program on Chemical Safety. 1991. Environmental Health Criteria 118: Mercury. Geneva: World Health Organization, 168p.

Wulf HC, Kromann N, Kousgaard N, Hansen JC, Niebuhr E \& Alboge K. 1986. Sister chromatid exchange (SCE) in Greenlandic Eskimos. Doseresponse relationship between SCE and seal diet, smoking and blood cadmium and mercury concentrations. Sci Total Environ 48: 81-94. 
Yamada H, Miyahara T, Kozuka H, Matsuhashi T \& SASAKI YF. 1993. Potentiating effects of organomercuries on clastogen-induced chromosome alterations in cultured Chinese hamster cells. Mutat Res 290(2): 281-91. 